\title{
Compression performance and bearing capacity calculation model of small-eccentricity columns strengthened with textile-reinforced mortar (TRM)
}

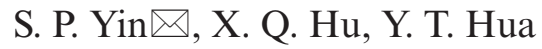 \\ State Key Laboratory for Geomechanics \& Deep Underground Engineering, School of Mechanics \& Civil Engineering, \\ China University of Mining and Technology, (Jiangsu, Xuzhou, China) \\ $\triangle$ yinshiping2821@163.com
}

Received 4 August 2018

Accepted 5 February 2019

Available on line 25 June 2019

\begin{abstract}
To study the compression performance of TRM-strengthened columns with small eccentricities, a total of 9 reinforced concrete (RC) columns with end corbels were subjected to compression testing. The test parameters are as follows: the number of textile layers, the ratio of longitudinal reinforcement, and polyvinyl alcohol (PVA) short-cut fiber volume fraction. The experimental results indicated that, compared to the control, columns with three layers of textile exhibited an approximately $10.66 \%$ increase in the bearing capacity. However, the effect increased only slightly when the number of textile layers increased to 4 . Besides, the effect was improved with the increase in the ratio of longitudinal reinforcement and PVA fiber volume fraction. Finally, based on laboratory tests and related research results, a model for calculating normal section bearing capacity of TRM-strengthened columns with small eccentricities was presented. A comparison of the theoretical and experimental data demonstrated the applicability of the proposed model.
\end{abstract}

KEYWORDS: Composite; Fiber reinforcement; Mechanical properties; Modelization.

Citation/Citar como: Yin, S.P.; Hu, X.Q.; Hua, Y.T. (2019) Compression performance and bearing capacity calculation model of small-eccentricity columns strengthened with textile-reinforced mortar. Mater. Construcc. 69 [335], e195 https://doi.org/10.3989/mc.2019.08418

RESUMEN: Modelo de cálculo del rendimiento a compresión y capacidad de carga de columnas con pequeñas excentricidades reforzadas con mortero reforzado con textiles (TRM). En este trabajo se estudió el rendimiento a compresión de columnas reforzadas con TRM con pequeñas excentricidades, y para ello, se sometieron a pruebas de compresión a nueve columnas de hormigón armado (RC) con ménsulas finales. Los parámetros estudiados fueron: el número de capas textiles, la relación de refuerzo longitudinal y la fracción en volumen de fibras cortas de alcohol polivinílico (PVA). Los resultados experimentales indicaron que, en comparación con el control, las columnas con tres capas de textiles mostraron un aumento de aproximadamente el 10,66\% en la capacidad de carga. Sin embargo, el aumento fue ligero cuando el número de capas textiles aumentó a cuatro. Además, el efecto mejoró con el aumento en la proporción de refuerzo longitudinal y la fracción en volumen de fibras de PVA. Finalmente, basándonos en las pruebas de laboratorio y resultados de investigación previos, se presentó un modelo para calcular la capacidad de carga de la sección normal de columnas reforzadas con TRM con pequeñas excentricidades. Una comparación de los datos teóricos y experimentales demostró la aplicabilidad del modelo propuesto.

PALABRAS CLAVE: Composite; Refuerzo de fibras; Propiedades mecánicas; Modelización.

ORCID ID: S.P. Yin (https://orcid.org/0000-0001-8304-5914); X.Q. Hu (https://orcid.org/0000-0002-9902-8585); Y.T. Hua (https://orcid.org/0000-0001-6248-9807)

Copyright: (C) 2019 CSIC. This is an open-access article distributed under the terms of the Creative Commons Attribution 4.0 International (CC BY 4.0) License. 


\section{INTRODUCTION}

Existing concrete structures often need to be repaired and reinforced due to various reasons, such as design flaws, construction mistakes, function changes, and natural disasters. Therefore, civil engineers have been committed to the research and development of strengthening materials. Fiber-reinforced polymer (FRP) is now widely used as a strengthening material (1) for reinforced concrete (RC) structures as a result of its outstanding performance (low weight, high ductility, and high resistance to corrosion). Extensive studies (2) have proven that FRP confinement can be used to strengthen damaged or deteriorated RC columns. However, FRP has a few shortcomings (3): poor fire resistance, low durability and poor thermal compatibility with the base concrete. For new methods of corrosion resistance for steel bars, it is more economical to use cementbased materials as repair materials.

In recent years, some new composite materials for strengthening RC structures have been proposed, including textile-reinforced concrete (TRC) (4-5), textile-reinforced mortar (TRM) (6), fiberreinforced concrete (FRC) (5), and fiber-reinforced cementitious matrix (FRCM) (7), whose effectiveness have been proved by experimental studies. These systems are merely variations of the same core idea with typically minor differences. Textilereinforced morter (TRM) is made of a multiaxial textile and fine-grained concrete, and it can not only repair the defects and cracks on the surface of the structure but also provide a cover that resists corrosion of the damaged structure (8). Due to the excellent anti-crack performance, anti-corrosion capacity and seepage resistance, TRM is widely used for strengthening reinforced concrete structures.

Currently, many scholars have conducted experimental studies on the performance of $\mathrm{RC}$ beams and plates (9-11) strengthened with TRM. However, studies on columns strengthened with TRM are relatively rare. Papanicolaou (12) found that TRM could improve the compressive strength and deformability of $\mathrm{RC}$ columns and that the enhancement effect becomes more obvious with the increase in reinforcement layers. Bournas et al. (13) found that TRM could enhance the deformation capacity of a column by delaying buckling of the longitudinal bars, and this effect is related to the volumetric ratio of the TRM wrap. A stress-strain model (14) of FRCM-confined concrete members was proposed to effectively predict the performance of the cylindrical members. Moreover, it has been noted in the literature (7) that longitudinal FRCM confinement can greatly improve the ductility and deformability of columns under eccentric compression loading. In addition, the structural behavior of eccentrically loaded concrete columns strengthened with FRCM was also studied (3); test parameters included the load eccentricity and the confinement reinforcement ratio. The results showed that FRCM could increase the strength of eccentrically loaded concrete columns, and the strength gain increased with the confinement reinforcement ratio but was inversely proportional to the eccentricity.

Most of the research cited above was devoted to the behavior of TRM-strengthened concrete columns under an axial load, while knowledge of reinforced columns under an eccentric load is lacking. The above analysis shows that the existing research does not involve the influence of the longitudinal reinforcement ratio or PVA fiber on the compression performance of strengthened columns. Since nearly all columns in practical engineering are subjected to a combination of axial load and bending moment, further research is required to explore the compression performance of eccentric compression columns strengthened with TRM. In view of these concerns, this paper conducts experimental research on the strengthening effect of TRM with different numbers of textile layers, ratio of longitudinal reinforcement and PVA short-cut fiber volume fractions. Previous similar experimental campaigns have been developed on this topic and there is a model for calculating the sectional force available in the literature (3). However, in the process of calculating the effective lateral confining pressure, the influence of cross section shape and uneven longitudinal restraint did not be considered. In order to consider the actual situation more comprehensively, the bearing capacity calculation model of TRM-strengthened columns under an eccentric load is proposed in the hopes that it can provide theoretical guidance for the application of TRM in engineering practice.

\section{EXPERIMENTAL PROGRAM}

\subsection{Configuration of test specimens}

There were 9 rectangular RC columns in this test, the overall length of which was $800 \mathrm{~mm}$. The two end corbels had a cross section of $120 \mathrm{~mm} \times 250 \mathrm{~mm}$ and were $200 \mathrm{~mm}$ long. The tested specimens were subjected to eccentric compression with $35 \mathrm{~mm}$ of load eccentricity, and the parameters are shown in Table 1. Each tested specimen had a cross section of $120 \mathrm{~mm} \times 150 \mathrm{~mm}$ in the test region. The longitudinal reinforcement consisted of four HRB400 steel bars, and the shear reinforcement consisted of 6.5-mm-diameter HPB300 stirrups spaced at 100 $\mathrm{mm}$ in the test region, as shown in Figure 1. For convenient application of the eccentric load, the two ends of the columns were designed as corbel shapes, at the steel bars on the tensile side were bent into the corbel shape and used as oblique compression reinforcement. A steel plate with a thickness of 10 $\mathrm{mm}$ was placed at the end of the column to prevent 
TABLE 1. Specimen parameters

\begin{tabular}{lccc}
\hline $\begin{array}{l}\text { Specimen } \\
\text { number }\end{array}$ & $\begin{array}{c}\text { The diameter } \\
\text { of longitudinal } \\
\text { reinforcement }(\mathbf{m m})\end{array}$ & $\begin{array}{c}\text { Number of } \\
\text { textile layers }\end{array}$ & $\begin{array}{c}\text { Short-cut } \\
\text { fiber }\end{array}$ \\
\hline C0 & 10 & 0 & $/$ \\
C1 & 10 & 1 & $/$ \\
C2 & 10 & 2 & $/$ \\
C3 & 10 & 3 & $/$ \\
C4 & 10 & 4 & $/$ \\
C5 & 12 & 2 & $/$ \\
C6 & 14 & 2 & $/$ \\
C7 & 10 & 2 & $0.3 \%$ \\
C8 & 10 & 2 & $0.6 \%$ \\
\hline
\end{tabular}

Note: the short-cut fiber content is in accordance with volume fraction.
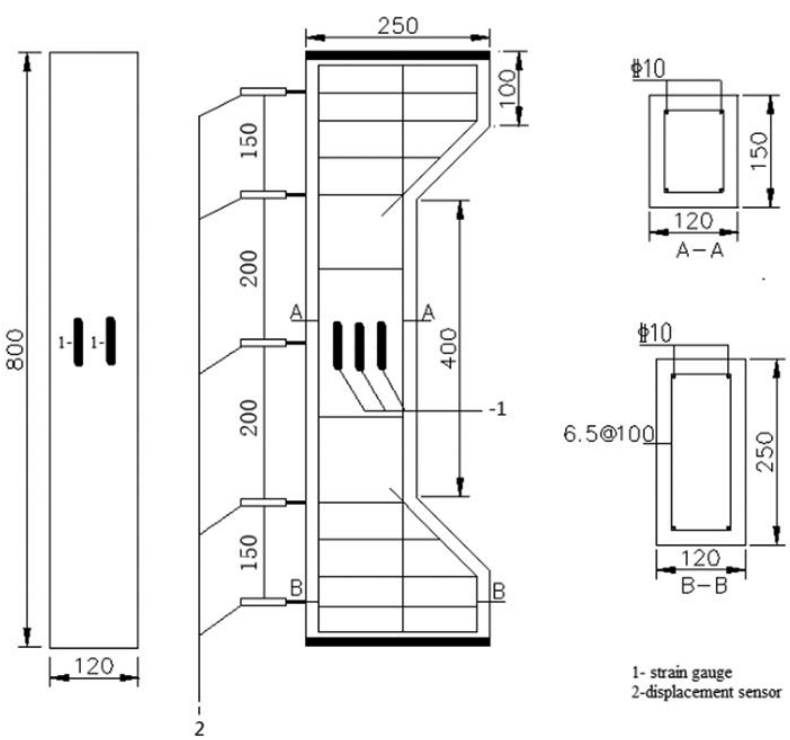

1- strain gauge 1- strain gauge
2-displacement sensor

FIGURE 1. Test setup and steel bars configuration of specimen (units in $\mathrm{mm}$ ). partial crushing, and 3 layers of 100 -mm-wide carbon fiber cloth were attached at two end corbels.

\subsection{Material properties}

\subsubsection{Concrete}

The strength grade of the concrete was $\mathrm{C} 40$, and the mix proportion was shown in Table 2 . The average compressive strength on the cubes with dimensions of $150 \mathrm{~mm} \times 150 \mathrm{~mm} \times 150 \mathrm{~mm}$ was $45.5 \mathrm{MPa}$ after 28 days of standard curing.

\subsubsection{Textile material}

The strengthening system consisted of a new type of hybrid material made out of textile embedded within fine-grained concrete as a matrix, and the low tensile strength of the matrix was compensated by using a high capacity textile. As shown in Figure 2, the hybrid textile was composed of weft carbon fiber bundles (T700S) and warp alkali-free glass (E-glass) fiber bundles, and the mesh size is 10 $\mathrm{mm} \times 10 \mathrm{~mm}(15)$. The weft was laid in the direction of maximum enhancement, in the direction of the carbon fiber yarn. E-glass fiber cannot withstand alkaline conditions in concrete for a long period; thus, its load-carrying contribution was used merely to affix the carbon fiber. The mechanical properties of the textile were gathered from the literature (15) and are shown in Table 3.

TABLE 2. Mix proportion of concrete

\begin{tabular}{lccccc}
\hline & $\begin{array}{c}\text { Portland } \\
\text { cement PII }\end{array}$ & & & & \\
Component & $\mathbf{5 2 . 5 R}$ & water & sand & stone & $\begin{array}{c}\text { water } \\
\text { reducer }\end{array}$ \\
\hline $\begin{array}{l}\text { Content } \\
\left(\mathrm{kg} / \mathrm{m}^{3}\right)\end{array}$ & 475 & 161 & 643 & 1181 & 2.85 \\
\hline
\end{tabular}

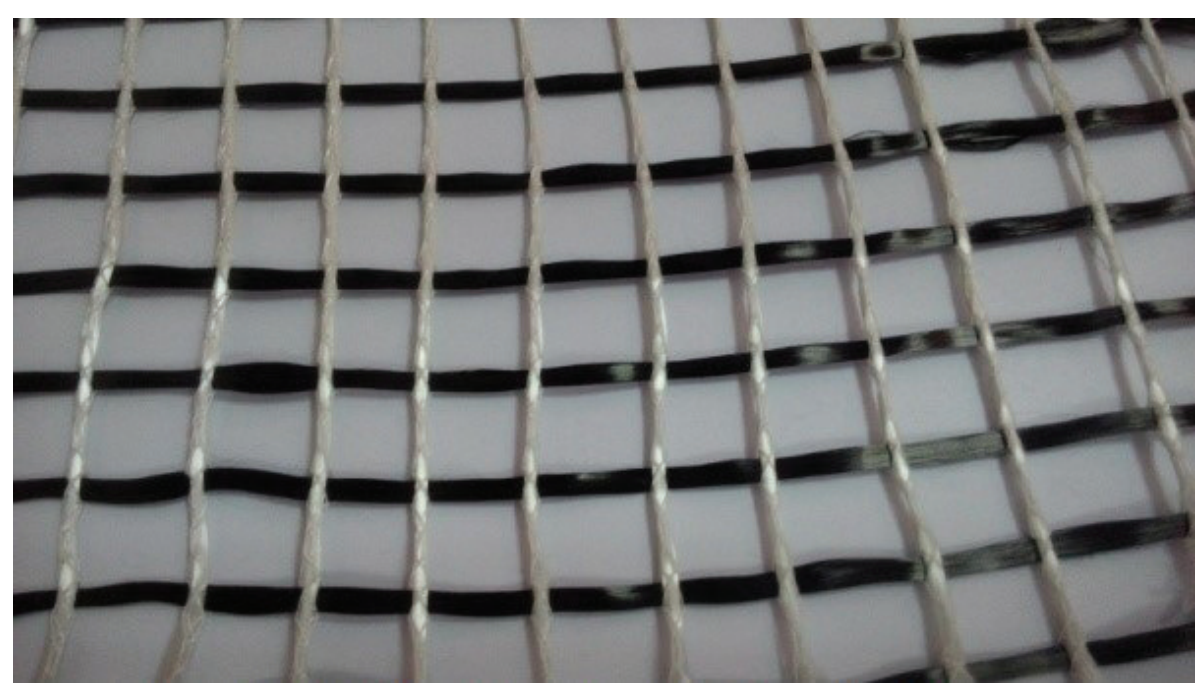

Figure 2. Textile material. 
TABLE 3. Mechanical properties and geometric parameters of fiber yarns of textile

\begin{tabular}{lcccccc}
\hline Fiber type & $\begin{array}{c}\text { Number of filaments } \\
\text { per yarn }\end{array}$ & $\begin{array}{c}\text { Filament tensile } \\
\text { strength (MPa) }\end{array}$ & $\begin{array}{c}\text { Filament elastic } \\
\text { modulus }(\mathbf{G P a})\end{array}$ & $\begin{array}{c}\text { Filament ultimate } \\
\text { strain } \mathbf{( \% )}\end{array}$ & $\begin{array}{c}\text { Yarn tex } \\
(\mathbf{g} / \mathbf{k m})\end{array}$ & $\begin{array}{c}\text { Yarn density } \\
\left(\mathbf{g} / \mathbf{c m}^{3}\right)\end{array}$ \\
\hline $\begin{array}{l}\text { Toray carbon } \\
\text { (T700S) }\end{array}$ & $12 \mathrm{k}$ & 4660 & 231 & 2 & 801 & 1.78 \\
E-glass & $4 \mathrm{k}$ & 3200 & 65 & 4.5 & 600 & 2.58 \\
\hline
\end{tabular}

TABLE 4. Mix proportion of fine-grained concrete

\begin{tabular}{lccccccc}
\hline Component & $\begin{array}{c}\text { Portland cement } \\
\text { PII 52.5R }\end{array}$ & Fly ash & $\begin{array}{c}\text { Silica } \\
\text { fume }\end{array}$ & Water & $\begin{array}{c}\text { Silica sand } \\
(\mathbf{0}-\mathbf{0 . 6} \text { mm) }\end{array}$ & $\begin{array}{c}\text { Silica sand } \\
(\mathbf{0 . 6}-\mathbf{1 . 2} \text { mm })\end{array}$ & $\begin{array}{c}\text { Super } \\
\text { plasticizer }\end{array}$ \\
\hline Content $\left(\mathrm{kg} / \mathrm{m}^{3}\right)$ & 475 & 168 & 35 & 262 & 460 & 920 & 9.1 \\
\hline
\end{tabular}

TABLE 5. Geometric and mechanical properties of PVA fiber

\begin{tabular}{lccccccc}
\hline Type & Dtex & $\begin{array}{c}\text { Length } \\
(\mathbf{m m})\end{array}$ & $\begin{array}{c}\text { Diameter } \\
(\mathbf{m m})\end{array}$ & $\begin{array}{c}\text { Tensile Strength } \\
(\mathbf{M P a})\end{array}$ & $\begin{array}{c}\text { Elongation } \\
(\%)\end{array}$ & $\begin{array}{c}\text { Tensile modulus } \\
(\mathbf{G P a})\end{array}$ & $\begin{array}{c}\text { Density } \\
\left(\mathbf{g} / \mathbf{c m}^{3}\right)\end{array}$ \\
\hline $\begin{array}{l}\text { Kuralon K-II } \\
\text { Rec15 }\end{array}$ & 15 & 12 & 0.04 & 1600 & 6 & 40 & 1.3 \\
\hline
\end{tabular}

\subsubsection{Fine-grained concrete}

The mix proportion was provided in the literature (16), as shown in Table 4. The measured compressive strength of the cubes with dimensions of 70.7 $\mathrm{mm} \times 70.7 \mathrm{~mm} \times 70.7 \mathrm{~mm}$ at 28 days was $52.8 \mathrm{MPa}$.

\subsubsection{Polyvinyl alcohol short-cut fiber}

The addition of PVA fiber to fine-grained concrete can improve not only its toughness (17) but also its interfacial adhesion with the textile and can resist concrete cracking. The geometric and mechanical properties of PVA short-cut fiber are shown in Table 5.

\subsection{Manufacturing process}

Before the reinforcement, the surface of the test region of the RC column was chiseled within the height range of $400 \mathrm{~mm}$. In order to prevent the occurrence of stress concentration in the column edges, a corner radius of $20 \mathrm{~mm}$ was then applied to the specimens. The whole reinforcing process of the specimen was as follows: First, clean and wet the surface of the column. Second, apply finegrained concrete to the surface of the column, with a thickness of approximately $2 \mathrm{~mm}$. Third, lay the textile horizontally along the test region of RC column with a lap length of $200 \mathrm{~mm}$ (the available anchorage length of the FRCM should exceed the minimum development length of 152 $\mathrm{mm}$ according to the ACI 549.4R-13 (18)). Fourth, after the first matrix layer is spread on the surface of the RC column, apply the fine-grained concrete to the surface of the textile. If multiple layers of textile are needed, repeat the above steps. Finally, cure the textile reinforced mortar for the standard curing age. The application of TRM is shown in Figure 3.

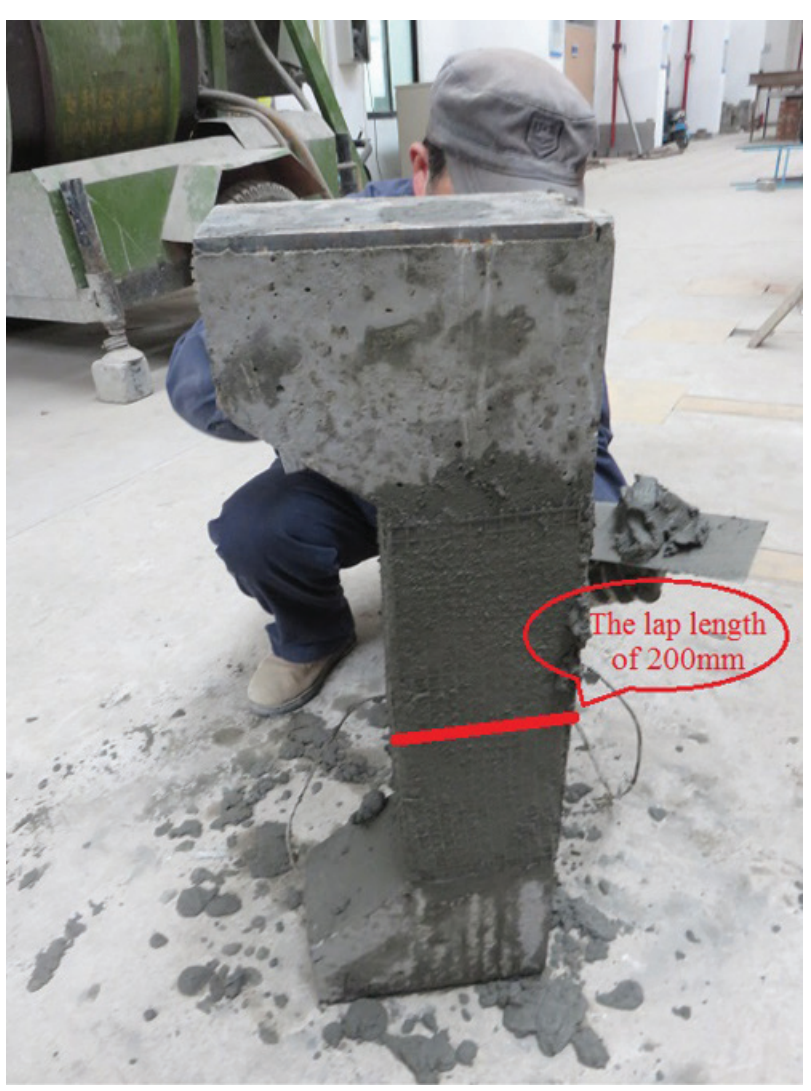

FIGURE 3. Strengthening process. 


\subsection{Testing and loading procedure}

In this experiment, a 7,000 $\mathrm{kN}$ pressure tester was used for loading. The test setup is provided in Figure 1; displacement sensors were placed at $1 / 4$ height, $1 / 2$ height, and $3 / 4$ height and the ends of the column to measure the lateral deflection due to the eccentric compression applied to the column. To measure the change law of the section strain during the test process, 3 concrete strain gauges were uniformly spaced in the middle part of the column, and 2 concrete strain gauges were placed in the middle part of the other two sides. In addition, the strain gauges were arranged on the surface of the longitudinal steel bar in the column to measure the development of the strain during the test process. The grid sizes of the steel strain gauges and the concrete strain gauges are $2 \mathrm{~mm} \times 1 \mathrm{~mm}$ and $100 \mathrm{~mm} \times 1 \mathrm{~mm}$ respectively, and the resistance values and sensitivity coefficients of the two types of gauges are the same: $119.7 \pm 0.1 \Omega$ and $2.08 \% \pm 1 \%$, respectively.

In this test, the specimens were measured under static loading conditions and positioned according to geometric alignment. Preloading was designed and implemented before the start of the test to not only eliminate the influence of the bearing offset but also ensure normal operation of the measuring instruments and the test equipment. A multistage loading was adopted for the test, and the loading rate was $10 \mathrm{kN} / \mathrm{min}$. When the load was $90 \%$ of the theoretical bearing capacity, the load of each stage was increased by less than $5 \%$ of the limit load. After the completion of each stage, the loading was maintained for 10 minutes. The relevant data cannot be recorded until the readings of the test instruments are stable.

\section{EXPERIMENTAL RESULTS AND DISCUSSION}

\subsection{Failure mode}

A summary of test results is shown in Table 6 . The characteristic failure modes of the specimens are shown in Figure 4, there are two types of failure modes. For column C0, which was not strengthened with TRM, there were no obvious changes on the surface of the specimen in the early stage. When approaching its ultimate load, there were a number of subtle longitudinal cracks near the side with the vertical load. After continuous loading of column $\mathrm{C} 0$, the cracks developed rapidly. Several transverse cracks appeared on the section far away from the vertical pressure. At the ultimate load, C0 failed suddenly by crushing the concrete near the compression side, with compression steel buckling to the outside, as shown in Figure 4. There was no obvious indication of potential failure before the column was destroyed due to brittle damage. For a reinforced column, the deformation was similar to that of $\mathrm{C} 0$ in the previous period. When the load approached $90 \%$ of the ultimate load, a small number of longitudinal cracks appeared on one side of the vertical load. As the load continued to increase, cracks developed quickly. When the failure load was reached, the stress concentration at the column corner ruptured the textile. The failure of the columns strengthened with one and two textile layers first appeared in the mid-height of the column due to the fracture of the fibres. Then, the separation of the TRM from the core concrete occurred in the middle of the column near the compression side of the axial force, and the inner concrete was crushed and bent outward, as shown in Figure 4. On the tensile side, obvious transverse cracks appeared on

TABLE 6. Test results of specimens

\begin{tabular}{lccll}
\hline Research factors & Specimen number & $\begin{array}{c}\text { Ultimate bearing } \\
\text { capacity }(\mathbf{k N})\end{array}$ & $\begin{array}{l}\text { Increase rate of bearing } \\
\text { capacity (decrease rate) }\end{array}$ & Failure mode \\
\hline Number of textile layers & $\mathrm{C} 0$ & 580.0 & contrast column & first type \\
& $\mathrm{C} 1$ & 608.0 & $4.8 \%$ & first type \\
& $\mathrm{C} 2$ & 621.4 & $7.1 \%$ & first type \\
& $\mathrm{C} 3$ & 641.8 & $10.7 \%$ & second type \\
& $\mathrm{C} 4$ & 642.5 & $10.8 \%$ & second type \\
Ratio of longitudinal & $\mathrm{C} 2$ & 621.4 & contrast column & first type \\
reinforcement & $\mathrm{C} 5$ & 624.4 & $0.5 \%$ & first type \\
& $\mathrm{C} 6$ & 636.8 & $2.5 \%$ & first type \\
PVA short-cut fiber & $\mathrm{C} 2$ & 621.4 & contrast column & first type \\
& $\mathrm{C} 7$ & 623.5 & $0.3 \%$ & first type \\
\hline
\end{tabular}



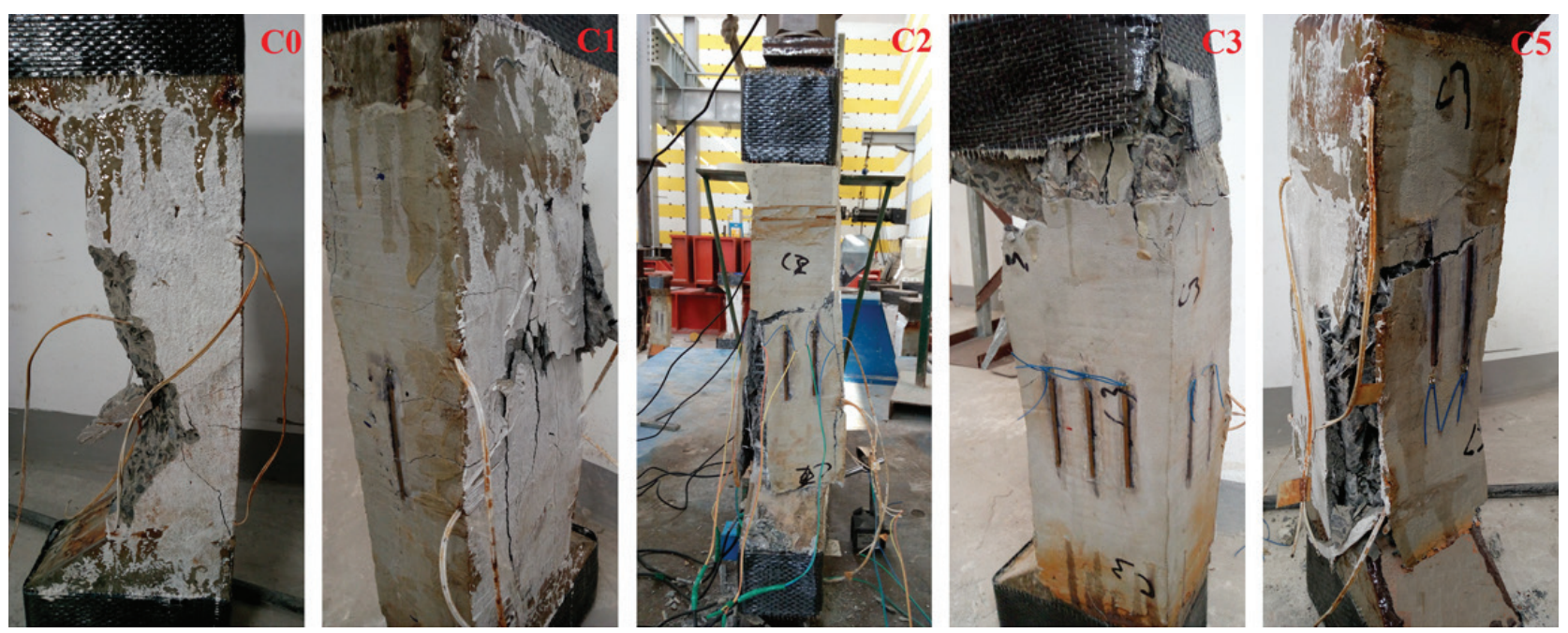

FIGURE 4. Failure modes of columns.

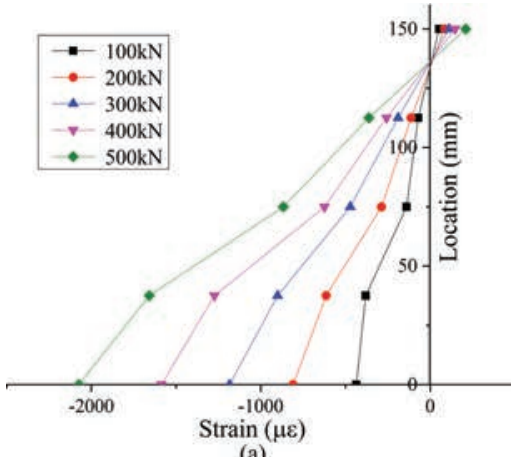

(a)

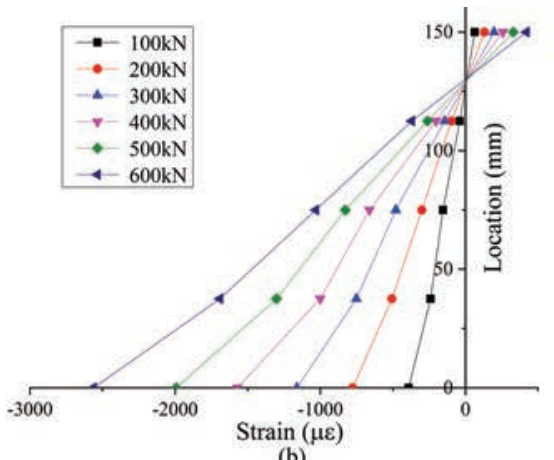

(b)

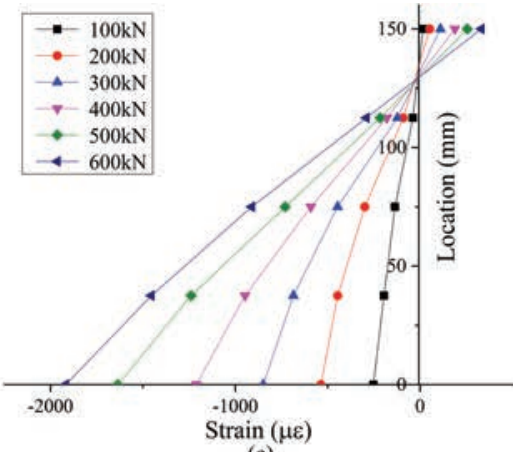

(c)

FIGURE 5. Load-strain curves of TRM-strengthened columns: (a) C0; (b) C2; (c) C5.

the surface of the TRM in the middle of the column, almost cutting through the cross section of the column; this was the first type of destruction. In addition, the TRM was destroyed at the upper part of column $\mathrm{C} 3$ and $\mathrm{C} 4$; this was the second type of destruction.

After reinforcement, the failure of the column was delayed, and the ductility was enhanced. When the column was strengthened with 3 layers, the damage of the TRM occurred in the upper part of the column, and the transverse cracks on the tension side moved upward. The reason for this phenomenon was that the increase in the number of reinforcement layer improves the ring hoop action of TRM during the compression process. Therefore, the unreinforced part of the corbel was relatively weak, and the deformation was too large, causing damage to the upper part of the column and crushing the internal concrete. However, the ratio of longitudinal reinforcement and PVA short-cut fiber volume fraction had little influence on the failure mode of TRM-confined columns.

\subsection{Relation between the load and longitudinal strain}

The load-strain curves of the representative specimens $\mathrm{C} 0, \mathrm{C} 2$ and $\mathrm{C} 5$ are shown in Figure 5. In general, most of the cross section of a concrete column was in a state of compression, while a small part was in a state of tension. Most likely, at the $130 \mathrm{~mm}$ section, the strain was zero. After reinforcement with TRM, the strain of the cross section linearly increased with the load and basically conformed to the plane section assumption. According to Figure 5, the longitudinal strain of column $\mathrm{C} 2$ was smaller than that of the column without strengthening measures under the same load. This shows that the TRM can better restrain the deformation of the eccentric column and improve its bearing capacity. From a comparison with the load-strain curves of $\mathrm{C} 2$, it can be found that the longitudinal strain of $\mathrm{C} 5$ with a high reinforcement ratio is smaller under the same load, indicating that the ultimate bearing capacity of $\mathrm{C} 5$ was improved. 


\subsection{Relation between load and mid-height lateral deformation}

\subsubsection{Effect of different numbers of textile layers}

As shown in Table 6, the ultimate bearing capacity of unreinforced column $\mathrm{C} 0$ was $580 \mathrm{kN}$. Compared with ultimate bearing capacity of $\mathrm{C} 0$, the corresponding ultimate bearing capacity of the reinforced columns was increased by $4.83 \%$, $7.14 \%, 10.66 \%, 10.78 \%$ as the number of textile layers increased from one to four, respectively. It can be seen that the ultimate bearing capacity of the columns increased greatly as the number of textile layers increased from one to three, but the improvement was not obvious when the number of textile layers increased from three to four. The load and mid-height lateral deformation curves of all the specimens are shown in Figure 6. Figure 6(a) illustrated that at the early stage of loading, the deformation increased linearly with the load. As the load gradually increased, the deformation of the columns increased nonlinearly. From Figure 6(a), we can see that the rate of this increase continuously increased, and the slope of the entire curve decreased. When the load approached the ultimate load, the deformation clearly increased without abrupt strengthened column failure, similarly as was the case with the FRCM-confined columns (7).

\subsubsection{Effect of different longitudinal reinforcement ratio}

The longitudinal reinforcement ratio of eccentrically loaded columns C2, C5, C6 were 1.01\%, 1.45\% and $1.97 \%$ respectively. As shown in Table 6 , corresponding ultimate bearing capacities were 621.4 $\mathrm{kN}, 624.4 \mathrm{kN}$, and $636.8 \mathrm{kN}$. For example, the ultimate bearing capacity of C5 and C6 increased by $0.48 \%$ and $2.48 \%$, respectively, compared to that of $\mathrm{C} 2$. With the increase in the reinforcement ratio, the bearing capacity of the small eccentricity columns increased gradually, but the range of increase was small. Figure 6(b) illustrates that the effect of reinforcement ratio on the mid-height lateral deformation was little. In addition, under the same load, the deformation of a column with a high reinforcement ratio was smaller than that with a low reinforcement ratio, although the range of decrease was low; this was consistent with a small increase in the ultimate bearing capacity. Therefore, the increase in the reinforcement ratio reduced the deformation of the columns, although by only $2.1 \%$ at a reinforcement ratio of $1.45 \%$. This was because the increase in reinforcement ratio has little influence on the failure mode and crack development of the columns, and the increase in stiffness was also small. This is a negative phenomenon due to the reduction of the longitudinal ductility of the TRM-strengthened concrete columns.

\subsubsection{Effect of different PVA short-cut fiber volume fractions}

As shown in Table 6, compared with C2, the PVA short-cut fiber volume fraction in the TRM of columns $\mathrm{C} 7$ and $\mathrm{C} 8$ were $0.3 \%$ and $0.6 \%$, respectively, and their ultimate bearing capacities were $623.5 \mathrm{kN}$ and $629.8 \mathrm{kN}$, representing increases of $0.34 \%$ and $1.35 \%$. When the volume of PVA short-cut fiber in the TRM was small, the ultimate bearing capacity of the eccentrically loaded columns increased gradually with the volume, but only marginally. This also proves the contribution of mortar matrix to bearing capacity of TRM-strengthened concrete columns should be neglected (18). The three curves of the load and mid-height lateral deformation of columns C2, C7, and C8 approximately coincided, as we can see from Figure 6(c). Notably, a deformation reduction of only $2.9 \%$ was recorded. This shows that PVA short-cut fiber has little influence on delaying the development of cracks and the stiffness of the column during the compression process. In addition, a possible reason was that although the PVA short-cut fiber improves the interfacial adhesion between fine-grained concrete and the hybrid textile, but it has less impact on improving the bond strength between the TRM and old column.

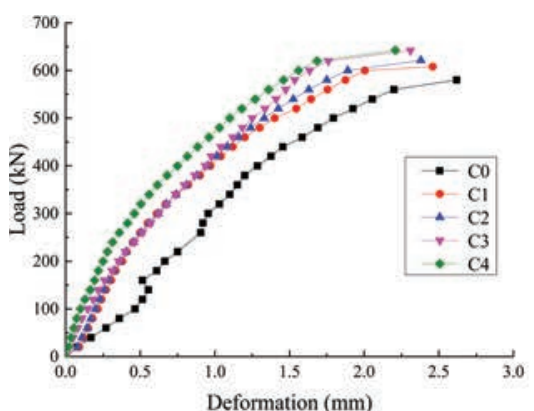

(a)

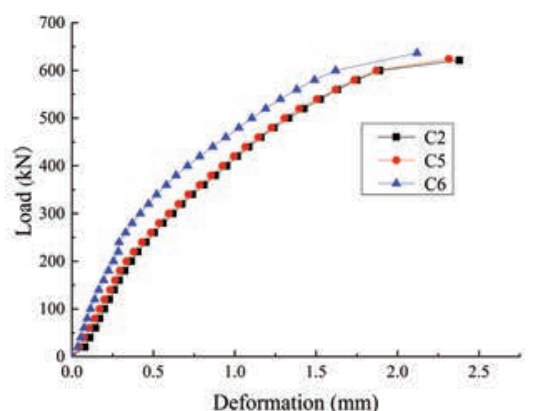

(b)

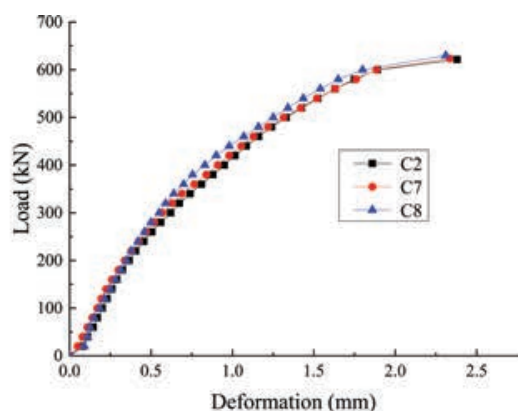

(c)

FIGURE 6. Load-midspan deformation curves under different conditions: (a) numbers of textile layers; (b) ratio of longitudinal reinforcement; (c) PVA short-cut fiber volume fraction. 
Furthermore, the bearing capacities of the three columns were approximately the same, which lead to approximately the same deformations.

\section{CALCULATION OF NORMAL SECTION BEARING CAPACITY}

\subsection{Fundamental assumption}

1. The tensile stress of the fine-grained concrete and concrete is not considered.

2. The average strain in measurement distance of the column strengthened with the TRM basically satisfies the plane section assumption; the constraint of the textile of the rectangular section is not heterogeneous, and only the effective constraint is considered for the safety and convenience of calculation.

3. As the TRM reinforcement layer is thin, the increase in section thickness is neglected in order to simplify the calculation; there are effective bonds between the fine-grained concrete and textile materials, and no debonding failure occurs.

4. There is no relative slippage either between the concrete and steel bars or between the finegrained concrete and textile.

\subsection{Proposal of constraint model}

The limitation of compressed elements' transverse strains is achieved by FRP and TRM wrapping, so the basic principle for both systems was similar (19). On the basis of the model of concrete confined with carbon fiber sheet, which has been studied and proven to be effective (20), the constraint model of the TRM is obtained analogously. Referring to the restraining action of rectangular columns strengthened with FRCM (18), the regional confinement of TRM is shown in Figure 7. Because of the influence of the section size on the textile layer in TRM, the constraint on the rectangular section in the compression process is uneven, and an effectively confined region and a weakly confined region form.

Considering the weakening of the textile layer due to the section shape and column corner and referring to the simplified method in reference (18), an equivalent circle is derived in order to conveniently calculate the formula. That is, the diagonal length of the rectangular section is the diameter of the equivalent circle. Additionally, the formula considers the weakening caused by longitudinal and lateral non-uniform constraints, and the reduction coefficient $k_{f}$ of the tensile strength of the textile layers is introduced by the stress concentration at the column corner. The lateral confining strength (21) can be converted into [1]

$$
f_{l}=\frac{2 k_{e} k_{s} k_{f} f_{f} t_{f}}{\sqrt{h^{2}+b^{2}}}
$$

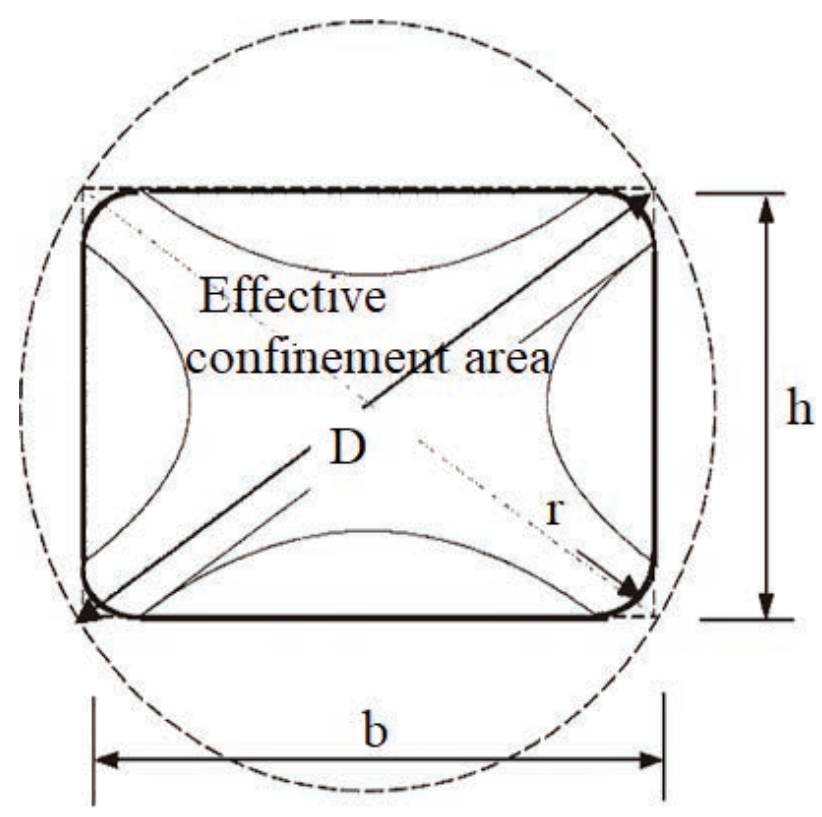

Figure 7. Equivalent circular cross section.

where $f_{l}$ is the equivalent lateral confining strength of the textile layer;

$k_{e}$ is the sectional influence coefficient;

$k_{s}$ is the weakening coefficient considering longitudinal non-uniform constraint;

$k_{f}$ is the reduction coefficient of the tensile strength of the textile layers due to the stress concentration at the column corner;

$k_{f}$ is the ultimate tensile strength of the textile layer;

$k_{f}$ is the thickness of the textile layer $\left(t_{f}=0.17 \mathrm{~mm}\right.$ in this test);

$h$ is the height of the rectangular section;

$b$ is the width of the rectangular section.

(1) sectional influence coefficient $k_{e}$

According to references $(18,21)$, the modified coefficient of the section shape is the ratio of the area of the effectively confined region to the entire area constrained by the fiber, that is [2],

$k_{e}=\left(\frac{b}{h}\right) \frac{1-\frac{\left[\left(\frac{b}{h}\right)\left(h-2 r_{c}\right)^{2}+\left(\frac{h}{b}\right)\left(b-2 r_{c}\right)^{2}\right]}{3 A_{g}}-\rho_{g}}{1-\rho_{g}}$

where $r_{c}$ is the corner radius of the rectangular section;

$A_{g}$ is the gross cross-sectional area of the rectangular section;

$r_{g}$ is the reinforcement ratio.

(2) weakening coefficient $k_{s}$

The presence of the fiber bundles spacing will result in uneven longitudinal restraint. Compared with the continuous wrapping of the 
fiber sheet, the lateral confining strength is reduced to some extent, that is [3],

$$
k_{s} \frac{(b-s / 2)(h-s / 2)}{b h}
$$

where $s$ is the spacing of the weft fiber bundles.

(3) reduction coefficient $k_{f}$ of the tensile strength of textile layers due to the stress concentration at the column corner.

It is noted in the literature (22) that the stress concentration at the corner section of the column leads to the weakening of the tensile strength of the textile layer, which is related to the corner radius and height of the rectangular section, that is [4],

$$
k_{f}=0.3+0.35\left(\frac{2 r_{c}}{b}\right)^{0.38}
$$

It is noted that the confinement of the textile layer around the concrete is similar to the hoop action of stirrups. Referring to the results of a concrete cylinder under three-directional pressure, a rectangular column is still subjected to the compressive stress around it. The compressive strength of the confined concrete $f_{c}$ is calculated by equation [5].

$$
f_{c}=f_{c 0}+4 f_{l}
$$

where $f_{c 0}$ is the compressive strength of the unconfined concrete.

\subsection{Calculating diagram and formula}

The calculating diagram for the column strengthened with TRM is shown in Figure 8. According to the equilibrium condition of force and moment, it can be obtained that

$$
N_{u}=\alpha_{1} f_{c} b x+f_{y}^{\prime} A_{s}^{\prime}-\sigma_{s} A_{s}
$$

$$
\begin{gathered}
N_{u} e=\alpha_{1} f_{c} b x\left(h_{0}-\frac{x}{2}\right)+f_{y}^{\prime} A_{s}^{\prime}\left(h_{0}-a_{s}^{\prime}\right) \\
\sigma_{s}=\frac{\xi-\beta_{1}}{\xi_{b}-\beta_{1}} f_{y}-f_{y}^{\prime} \leq \sigma_{s} \leq f_{y} \\
e=e_{i}+\frac{h}{2}-a_{s}
\end{gathered}
$$

where $x$ is the compression zone height of concrete, and when $x>h, x=h$;

$A_{s}$ is the area of tension steel, $A_{s}^{\prime}$ is the area of compression steel;

$\alpha_{1}$ is the ratio of the stress value to the $f_{c}$ in the equivalent rectangular stress block in the compression zone and is 1.0 (23);

$\beta_{1}$ is the ratio of the height of the compression zone in the equivalent rectangular stress block to the height of neutral axis assumed by the plane section assumption, and the value is 0.8 (23);

$N_{u}$ is the load-bearing ultimate capacity of the concrete column under a small eccentrically load;

$f_{y}$ is the design value of the tensile strength of tension steel, $f_{y}^{\prime}$ is the design value of compressive strength of compression steel;

$\sigma_{s}$ is the stress of the steel bar on the tensile side far from the vertical load;

$\xi$ is the relative height of the compression zone, that is, $\xi=x / h_{0}$, and $\xi_{b}$ is relative-boundary compressive region's height;

$h_{0}$ is the sectional effective height, $h_{0}=h-a_{s}$;

$e$ is the distance from the vertical load point to the resultant force point of the tensile reinforcement, $e_{i}$ is the initial eccentricity;

$a_{s}$ is the distance from the resultant force point of the tensile reinforcement to the edge of the tensile area; and $a_{s}^{\prime}$ is the distance from the resultant force point of the compression reinforcement to the edge of the compression area.
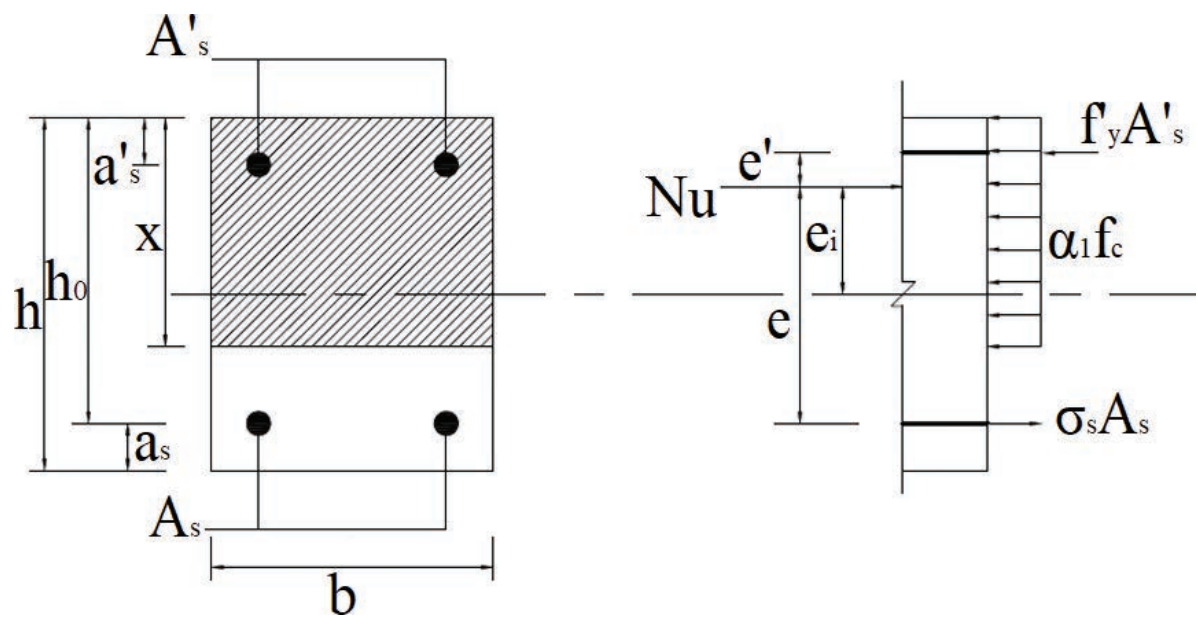

FIGURE 8. Calculating diagram of column strengthened with TRM. 


\subsection{Comparison between calculated and experimental values}

Combined with the above formula, the theoretical bearing capacity value of the column can be calculated by the following steps:

1. For a given external eccentricity $e_{i}$, calculate $e$ by using equation [9].

2. Calculate the equivalent lateral confining strength $f_{l}$ by using equations [1], [2], [3] and [4].

3 . Use the $f_{l}$ value to account for the $f_{c}$ value by using equation [5].

4. $\sigma_{s}$ in equation [6] can be replaced by $x$ (equation [8]).

5. In light of the equilibrium condition, the ultimate bearing capacity is evaluated by equations [6] and [7].

In this chapter, the effect of PVA fiber on the loading capacity of TRM-strengthened columns is very small, so its influence is not considered. According to the derived calculation formula, Table 7 gives the calculation values of the bearing capacity. The proposed model was also used to verify the experimental results (24) for FRCM confined concrete columns. It can be seen that the error becomes larger as the number of reinforcement layers increases, which is due to the failure to make full use of the tensile strength of the fibers. Besides, column C6, with a 14-mm-diameter longitudinal reinforcement, did not completely yield during the test. In the calculation, the strength of the longitudinal reinforcement of the compression side is taken as the yield strength, so the calculated value is larger. The relative error is within $10 \%$ for the remaining reinforced specimens, showing the accuracy of the model for designing TRM-strengthened concrete columns.

\section{CONCLUSIONS}

This paper examined the viability of textile-reinforced mortar to upgrade RC columns under eccentric loading, and a test was designed to provide better insight into the effect of the number of textile layers, the ratio of longitudinal reinforcement and the PVA short-cut fiber volume fraction on the compression performance of small-eccentricity columns. In addition, this paper proposed a preliminary model for TRM-confined RC columns. Due to the small number of specimens, more tests are needed to improve the model in the future. Based on the results of the experimental study, the following conclusions were obtained:

1. As a result of strong restrictions, the TRM composites allow an increase in the energy absorption capacity of reinforced concrete columns under eccentric compression. Compared with the unconfined columns, the increasing rate of the carrying capacity of the confined specimens ranged between $4.83 \%$ and $10.78 \%$.

2. The compression ability of concrete inside the column confined with TRM is enhanced, and an increase in the longitudinal reinforcement ratio has little influence on the strength. The ratio of the longitudinal bars is not the key factor to determine the development of cracks in TRM-strengthened concrete columns, so the deflection is reduced less.

3. The column confined by double strengthening layers that incorporate $0.6 \%$ PVA fibers exhibits an approximately $1.35 \%$ increase in the load carrying capacity over the unreinforced column.

4. The failure modes of the TRM-strengthened columns are dependent on the number of textile layers, while the ratio of longitudinal

TABLE 7. Comparison of calculated and experimental values

\begin{tabular}{|c|c|c|c|c|c|c|}
\hline Specimen number & $\begin{array}{c}\text { Number of } \\
\text { reinforcement } \\
\text { layers }\end{array}$ & $\begin{array}{l}\text { longitudinal bar } \\
\text { diameter } \\
(\mathbf{m m})\end{array}$ & $\begin{array}{l}\text { Eccentricity } \\
(\mathbf{m m})\end{array}$ & $\begin{array}{c}\text { Calculated value } \\
\qquad(\mathrm{kN})\end{array}$ & $\begin{array}{c}\text { Experimental } \\
\text { value } \\
(\mathbf{k N})\end{array}$ & Relative error \\
\hline $\mathrm{C} 1$ & 1 & 10 & 35 & 593.4 & 608.0 & $2.4 \%$ \\
\hline $\mathrm{C} 2$ & 2 & 10 & 35 & 656.7 & 621.4 & $5.7 \%$ \\
\hline C3 & 3 & 10 & 35 & 719.9 & 641.8 & $12.2 \%$ \\
\hline $\mathrm{C} 5$ & 2 & 12 & 35 & 690.5 & 624.4 & $10.6 \%$ \\
\hline C6 & 2 & 14 & 35 & 728.5 & 636.8 & $14.4 \%$ \\
\hline $\mathrm{C} 7$ & 2 & 10 & 35 & 656.7 & 623.5 & $5.3 \%$ \\
\hline $\mathrm{C} 8$ & 2 & 10 & 35 & 656.7 & 629.8 & $4.3 \%$ \\
\hline C-1H-16 [24] & 1 & 12 & 16 & 2096.0 & 1956.8 & $7.1 \%$ \\
\hline C-2H-16 & 2 & 12 & 16 & 2144.2 & 2043.65 & $4.9 \%$ \\
\hline C-1H-32 & 1 & 12 & 32 & 1714.6 & 1596.0 & $7.4 \%$ \\
\hline $\mathrm{C}-2 \mathrm{H}-32$ & 2 & 12 & 32 & 1753.7 & 1812.2 & $3.2 \%$ \\
\hline
\end{tabular}


reinforcement and PVA short-cut fiber volume fractions are not influential. For single or double layer confined columns, the failure is due to partial stripping of the TRM from the internal concrete in the compression zone. When the reinforcement includes three layers, the damage of the TRM occurs in the upper part of the column and the degree of exfoliation is reduced.

5. Referring to the mechanical properties of a rectangular column confined by FRP, a model for calculating the bearing capacity of small-eccentricity columns strengthened with TRM has been presented. The proposed calculation model is shown to agree with the existing test results presented in this paper, showing the applicability of the finished model for TRM-strengthened concrete columns. In future research, the test of columns with different sizes will be carried out to improve the model proposed in this paper.

\section{ACKNOWLEDGMENTS}

The authors gratefully acknowledge the financial support from the Program of the Fundamental Research Funds for the Central Universities (2017XKZD09). The experimental work described in this paper was conducted at the Jiangsu Key Laboratory of Environmental Impact and Structural Safety in Civil Engineering in the China University of Mining and Technology. Helps during the testing from staffs and students at laboratory are greatly acknowledged.

\section{REFERENCES}

1. Bournas, D.A.; Pavese, A.; Tizani, W. (2015) Tensile capacity of FRP anchors in connecting FRP and TRM sheets to concrete. Eng. Struct. 82, 72-81. https://doi.org/10.1016/j. engstruct.2014.10.031

2. Bisby, L.; Ranger, M. (2010) Axial-flexural interaction in circular FRP-confined reinforced concrete columns. Constr. Build. Mater. 24 [9], 1672-1681. https://doi. org/10.1016/j.conbuildmat.2010.02.024

3. Ombres, L.; Verre, S. (2015) Structural behaviour of fabric reinforced cementitious matrix (FRCM) strengthened concrete columns under eccentric loading. Compos. Pt. B-Eng. 75, 235-249. https://doi.org/10.1016/j. compositesb.2015.01.042

4. Xu, S.L.; Li, H. (2007) Bond Properties and Experimental Methods of Textile Reinforced Concrete. J. Wuhan Univ. Technol.-Mat. Sci. Edit. 22 [3], 529-532. https://doi.org/ $10.1007 / \mathrm{s} 11595-006-3529-9$

5. Mechtcherine, V. (2013) Novel cement-based composites for the strengthening and repair of concrete structures. Constr. Build. Mater. 41, 365-373. https://doi.org/10.1016/j. conbuildmat.2012.11.117

6. Papanicolaou, C.G.; Triantafillou, T.C.; Karlos, K.; Papathanasiou, M. (2007) Textile-reinforced mortar (TRM) versus FRP as strengthening material of URM walls: In-plane cyclic loading. Mater. Struct. 40 [10], 1081-1097. https://doi.org/10.1617/s11527-006-9207-8

7. Trapko, T. (2014) Behaviour of fibre reinforced cementitious matrix strengthened concrete columns under eccentric compression loading. Mater. Des. 54 [2], 947-954. https:// doi.org/10.1016/j.matdes.2013.09.008

8. Sheng, J.; Yin, S.P.; Wang, F. (2017) Experimental study on the fatigue behaviour of RC beams strengthened with TRC after sustained load corrosion. Constr. Build. Mater. 131, 713-720. https://doi.org/10.1016/j. conbuildmat.2016.11.030

9. Elsanadedy, H.M.; Almusallam, T.H.; Alsayed, S.H.; Alsalloum, Y.A. (2013) Flexural strengthening of RC beams using textile reinforced mortar-Experimental and numerical study. Compos. Struct. 97 [2], 40-55. https://doi. org/10.1016/j.compstruct.2012.09.053

10. Larbi, A.S.; Agbossou, A.; Hamelin, P. (2013) Experimental and numerical investigations about textile-reinforced concrete and hybrid solutions for repairing and/or strengthening reinforced concrete beams. Compos. Struct. 99, 152-162. https://doi.org/10.1016/j.compstruct.2012.12.005

11. Schladitz, F.; Frenzel, M.; Ehlig, D.; Curbach, M. (2012) Bending load capacity of reinforced concrete slabs strengthened with textile reinforced concrete. Eng. Struct. 40, 317-326. https://doi.org/10.1016/j.engstruct.2012.02.029

12. Triantafillou, T.C.; Papanicolaou, C.G.; Zissimopoulos, P.; Laourdekis, T. (2006) Concrete confinement with textilereinforced mortar jackets. ACI Struct. J. 103 [1], 28-37. https://doi.org/10.14359/15083

13. Bournas, D.A.; Lontou, P.V.; Papanicolaou, C.G.; Triantafillou, T.C. (2007) Textile-reinforced mortar versus fiber-reinforced polymer confinement in reinforced concrete columns. ACI Struct. J. 104 [6], 740-748. https://doi. org/10.14359/18956

14. Trapko, T. (2013) Stress-strain model for FRCM confined concrete elements. Compos. Pt. B-Eng. 45 [1], 1351-1359. https://doi.org/10.1016/j.compositesb.2012.07.001

15. Yin, S.P.; Xu, S.L.; Wang, F. (2015) Investigation on the flexural behavior of concrete members reinforced with epoxy resin-impregnated textiles. Mater. Struct. 48 [1-2], 153-166. https://doi.org/10.1617/s11527-013-0174-6

16. Yin, S.P.; Peng, C.; Jin, Z.Y. (2017) Research on mechanical properties of axial-compressive concrete columns strengthened with TRC under a conventional and chloride wet-dry cycle environment. J. Compos. Constr. 21 [1], 04016061. https://doi.org/10.1061/(asce)cc.1943-5614.0000725

17. Xu, S.L.; Li, Q.H.; Li, H.D. (2008) An experimental study on the flexural properties of carbon textile reinforced ECC. Chin. Civil. Eng. J. 40 [12], 69-76. https://doi. org/10.15951/j.tmgcxb.2007.12.010

18. American Concrete Institute (2013) Guide to design and construction of externally bonded fabric Reinforced Cementitious Matrix (FRCM) systems for repair and strengthening concrete and masonry structures. ACI 549.4R-13, ACI Committee 549. Farmington Hills, MI.

19. Trapko, T. (2014) Confined concrete elements with PBOFRCM composites. Constr. Build. Mater. 73, 332-338. https://doi.org/10.1016/j.conbuildmat.2014.09.055

20. Teng, J.G.; Huang, Y.L.; Lam, L.; Ye, L.P. (2007) Theoretical Model for Fiber-Reinforced Polymer-Confined Concrete. J. Compos. Constr. 11 [2], 201-210. https://doi.org/10.1061/ (ASCE)1090-0268(2007)11:2(201)

21. Pan, Y.; Cao, S.Y.; Jing, D.H.; Chen, D.B. (2009) Test and analysis of the axial stress-strain relationship of square section concrete columns confined by CFRP under preload. Chin. Civil. Eng. J. 42 [1], 23-29. https://doi.org/10.15951/j. tmgcxb.2009.01.012

22. Pan, Y.; Guo, R.; Li, H.G.; Tang, H.Y; Huang, J.X. (2017) Analysis-oriented stress-strain model for FRP-confined concrete with preload. Compos. Struct. 166 [3], 57-67. https://doi.org/10.1016/j.compstruct.2017.01.007

23. Yin S.P.; Xu, S.L.; Lv H.L. (2014) Flexural Behavior of Reinforced Concrete Beams with TRC Tension Zone Cover. J. Mater. Civ. Eng. 26 [2], 320-330. https://doi.org/ $10.1061 /$ (asce)mt.1943-5533.0000811

24. Trapko, T. (2014) Effect of eccentric compression loading on the strains of FRCM confined concrete columns. Constr. Build. Mater. 61, 97-105. https://doi.org/10.1016/ j.conbuildmat.2014.03.007 